\title{
Effects of formative assessments to develop self- regulation among sixth grade students: Results from a randomized controlled intervention
}

Citation for published version (APA):

Meusen-Beekman, K., Joosten-ten Brinke, D., \& Boshuizen, E. (2016). Effects of formative assessments to develop self-regulation among sixth grade students: Results from a randomized controlled intervention. Studies in Educational Evaluation, 51, 126-136. https://doi.org/10.1016/j.stueduc.2016.10.008

DOI:

10.1016/j.stueduc.2016.10.008

Document status and date:

Published: 05/11/2016

Document Version:

Other version

Please check the document version of this publication:

- A submitted manuscript is the version of the article upon submission and before peer-review. There can be important differences between the submitted version and the official published version of record. People interested in the research are advised to contact the author for the final version of the publication, or visit the DOI to the publisher's website.

- The final author version and the galley proof are versions of the publication after peer review.

- The final published version features the final layout of the paper including the volume, issue and page numbers.

Link to publication

\section{General rights}

Copyright and moral rights for the publications made accessible in the public portal are retained by the authors and/or other copyright owners and it is a condition of accessing publications that users recognise and abide by the legal requirements associated with these rights.

- Users may download and print one copy of any publication from the public portal for the purpose of private study or research.

- You may not further distribute the material or use it for any profit-making activity or commercial gain

- You may freely distribute the URL identifying the publication in the public portal.

If the publication is distributed under the terms of Article $25 \mathrm{fa}$ of the Dutch Copyright Act, indicated by the "Taverne" license above, please follow below link for the End User Agreement:

https://www.ou.nl/taverne-agreement

Take down policy

If you believe that this document breaches copyright please contact us at:

pure-support@ou.nl

providing details and we will investigate your claim.

Downloaded from https://research.ou.nl/ on date: 26 Apr. 2023 
Meusen-Beekman, K. D., Joosten-ten Brinke, D. \& Boshuizen, H. P. A. (2016). Effects of formative assessments to develop self-regulation among sixth grade students: Results from a randomized controlled intervention. Studies in Educational Evaluation, 51, 126-136.

Studies in Educational Evaluation 51 (2016) 126-136

\section{Effects of formative assessments to develop self-regulation among sixth grade students: Results from a randomized controlled intervention}

Kelly D. Meusen-Beekman ${ }^{\mathrm{a}, \mathrm{d}, *}$, Desirée Joosten-ten Brinke ${ }^{\mathrm{b}, \mathrm{c}}$, Henny P.A. Boshuizen ${ }^{\mathrm{b}, \mathrm{e}}$

a HZ University of Applied Sciences, The Netherlands

'Open University, The Netherlands

c Fontys University of Applied Sciences, The Netheriands

${ }^{\mathrm{d}}$ Roosevelt Centre for Excellence in Education, The Netherlands

-University of Turku, Finland

\section{A RTICLE I NFO}

\section{Article history}

Received 19 July 2015

Accepted 19 October 2016

Available online 5 November 2016

\section{Keywords:}

Formative assessment

Primary education

Selfregulation

Motivation

Self-efficacy
A B S T R ACT

This article presents the results of a formative assessment intervention in writing assignments in sixth grade. We examined whether the formative assessments (i.e. peer and self-assessment) would improve self-regulation, motivation and self-efficacy among sixth graders, and whether differential effects exist between formative assessment forms. The study lasted for 27 weeks. Participants ( $\mathrm{N}-695$ ) were exposed to one of three conditions: peer assessment intervention, self-assessment intervention, or a control condition. The interventions were delivered in a whole-classroom format. The results of a multilevel analysis showed that the use of formative assessment to develop self-regulation among students was effective for both intervention groups. Also, motivation was affected in both intervention groups. Finally, no significant differences were found between the peer assessment intervention and the self-assessment intervention concerning self-regulation, motivation, or self-efficacy. The implications of these results are discussed. 